\title{
The Role of Muslims in the Struggle Against Violent Extremist Ideology in Indonesia
}

\section{Ahmad Haris *}

Many recent acts of terrorism are believed to have roots in religious ideologies. Islam and its adherents are included among those suspected to be proponents of violent extremist ideology that promotes terrorism. This represents only part of the picture. While Islamic "revivalism" has emerged and proposes to establish an identity and to seek global justice, many Muslims in Indonesia have played significant roles in countering extremist ideology. Certainly, some extremist Muslims have inflicted significant harm upon humanity and the developed world. But several approaches could be implemented to minimize or eliminate the spread of terrorism or its ideology. This essay will review the status of Islamic extremism in Indonesia, and will briefly examine some of the efforts that have been made there to counter extremist ideology.

\section{Prologue}

The tragic events of 11 September 2001 - the destruction of the World Trade Center in New York and part of the Pentagon in Washington, D.C.- - as well as terrorist activities on Indonesian soil, such as the 2002 nightclub bombings at Legian Kuta in Bali, the J.W. Marriott Hotel in Jakarta, and other attacks, have killed or injured thousands of innocent people and created deep sorrow and sadness for the victims and their families. Many people regard those bombings as acts of terrorism, and the actors as terrorists.

In Indonesia alone, twenty-four terrorist bombings have occurred since 2000. Intelligence agencies attribute most of these actions to "hard-line” Indonesian Muslims, led by Dr. Azahari bin Husin and Noordin M. Top. These two figures are suspected to be linked to Osama bin Laden and Al Qaeda (Azahari was killed in November 2005; Top is still at large). ${ }^{1}$ Because of these associations, many Westerners increasingly regard Islam as a religion that sponsors terrorism, and have become hostile towards it.

The purpose of this paper is to describe the role of Muslims in the struggle against violent extremist ideology, particularly in Indonesia, one of the world's most populous

Ahmad Haris lectures on Islamic Studies and is the Vice Rector for Academic Affairs at The State Institute for Islamic Studies (IAIN) Sulthan Thaha Saifuddin Jambi, Indonesia. He participated in the 2004 Fulbright Visiting Specialist program by conducting dialogues on Islam with non-Muslims at a U.S. university. The original version of this paper was presented at the Marshall Center Alumni Leadership Seminar 2006, “Countering Ideological Support for Terrorism: Opportunities and Limitations in the Battle of Ideas,” Garmisch-Partenkirchen, Germany, 11-21 July 2006.

1 Hery Sucipto, “Radikalisasi Agama dan Strategi Pemberantasan Terorisme,” in Mehamami Indonesia, eds. Soegeng Sajadi and Sukardi Rinakit (Jakarta: Soegeng Sajadi Sindicate, 2006), 251-53. For Indonesians, the 9/11 tragedies and bombings in Indonesia were shocking. For thirty-two years, particularly during Suharto's reign, they rarely heard about or experienced bombings. 
Muslim countries. ${ }^{2}$ First, I will define the meaning of Islamic extremism, in order to differentiate it from such terms as fundamentalism and revivalism. Second, I will elaborate on any possible existence of such extremist activity in Indonesia, in order to explore the relationship between Muslims, particularly in Indonesia, and acts of extremism or terrorism. Third, I will discuss some ways to counter such extremism. This will illustrate how Indonesian Muslims play significant roles in rejecting violent extremist ideology. Finally, I will propose some ways to eliminate or minimize the spread of Islamic extremist ideology and acts of terror.

\section{Defining “Islamic” Extremism}

The terms extremist Islam or Islamic extremism are used interchangeably in academic literature with other common terms, such as Islamic fundamentalism and Islamic revivalism. To some extent, each term or movement describes a different vision. John Esposito, for example, characterizes fundamentalism as representing a return "to the fundamental faith of religion.” He criticizes people who carelessly use the term to imply extremism, fanaticism, political activism, terrorism, and anti-Americanism. Instead, Esposito employs the terms Islamic revivalism or Islamic activism to describe the movement of the contemporary Islamic awakening, because these terms, in his view, reflect traditional roots in Islam. ${ }^{3}$

Muhammad 'Abid Al-Jabiri uses the term Islamic extremism to refer to extremist Muslims who often direct their opposition against moderate Muslims. He believes that moderate Muslims are the longstanding enemy of extremist Muslims. He also distinguishes between extremist Islam in an earlier era and today. In the past, extremists focused their activities in the area of faith (akidah); now their attention centers on the area of sharia (the application of Islamic law) by waging war, if necessary, against the moderate schools of Islam. ${ }^{4}$

Muhammad Sa'id Al-Asymawi characterizes extremism as a movement trying to seize political power by manipulating religious (Islamic) issues. He argues that the dominant factor behind the emergence of extremist Islam is the mistrust of state, religious, and political institutions. Discourses on Islamic extremism have motivated them to infiltrate and utilize religious issues to seize power and rebel against the existing "secular" law. Hence, the significant factor in this movement is power. (This form of extremist Islam, which seeks to overthrow the structures of the secular state and replace it with a Muslim caliphate, is frequently referred to as Islamist, to distinguish it from more legitimate uses of the term Islamic.) In Islamic history, the Kharijite sect

2 Frans Magnis Suseno, “The Challenge of Pluralism," paper for the annual conference at the Postgraduate Programs of IAIN and UIN, Alauddin State Islamic University, Makassar, 2527 November 2005.

3 John L. Esposito, The Islamic Threat: Myth or Reality? (Oxford: Oxford University Press, 1992), 7-8.

4 Muhammad Abid Al-Jabiri, Al-Dîn wa al-Daulah wa Tathbîq al-Syarî'ah (Beirut: Markaz Dirâsât al-Wahdah al-’Arabiyah, 1997), 152-57. 
was notorious for mixing religious issues with political ones, and for using violence and intimidation to achieve their goals. ${ }^{5}$

The emergence of violent and radical movements is closely linked to religious issues. This provokes extremists to violent action. According to Yusuf Al-Qardawi, acts of violence and terrorism are triggered by fanaticism and intolerance, which extremists use to reject or isolate themselves from other possible interpretations. Moreover, extremists tend to force their ideas and inflexibility upon others. ${ }^{6}$ Once in a while, this overwhelming spirit (ghirah) explodes into active energy with the power to injure other people.

Up to this point, we could assert that "Islamic extremism” includes any immodest or immoderate action, attitude, interpretation, or practice of Islamic values. Such extremism can apply to both "left-" or "right-wing" Islam, though in fact the term $e x$ tremism is often directed more to the latter rather than the former. ${ }^{7}$ However, an Islamic extremist is not necessarily a Muslim terrorist. For instance, Abu Bakar Ba'asyir is often linked to $\mathrm{Al}$ Qaeda because of his extremist interpretation of Islam. He is also suspected of being the mastermind behind terrorist actions in Indonesia. ${ }^{8}$ He publicly expresses hatred of the United States as well as Australia, and propagates the implementation of sharia, or Islamic law, within a Muslim state structure. However, no strong evidence links him to terrorist movements in Indonesia or elsewhere. He has even been released from jail.

Nevertheless, extremist Muslims who interpret religious texts rigidly and stringently and regard people outside their circle as heretics are perceived as threats. When their agenda, ideology, and religious conviction converge and mix with specific personalities and groups, the ideology can become manifest in violent action. If they have access to sophisticated technology, extremists may pursue paths toward radical action

5 Muhammad Sa’id Al-Asymawi, Al-Islâm Al-Siyâsî (Cairo: Sina li al-Nasyr, 1987), 66. See also Al-'Asymawi's works in Against Islamic Extremism, ed. Carolyn Fluehr-Lobban (Gainesville, FL: University Press of Florida, 2001), especially 108-23.

6 See Yusuf Al-Qardawi, “Extremism,” in Liberal Islam: A Sourcebook, ed. Charles Kurzman (New York: Oxford University Press, 1998), 199-201. The term extremism is most often used to refer to strict conservative forms of Salafist Islam, which adheres to traditionalist interpretations and rigid observance of Islam. This includes groups such as Front Pembela Islam (the Front for Islamic Saviors), Hizb ut-Tahrir (the Liberation Party), and the Majelis Mujahidin Indonesia (the Mujahideen Council of Indonesia), among others. "Left-wing” Islam represents liberal Islam, a more rational branch of the faith that tries to accommodate Islam to foreign concepts such as secularism, pluralism, and liberalism. Liberal and fundamentalist Islam frequently engage in a battle of ideas and represent the two poles of Islamic thought. Although liberal Islam tends to be more extreme in its ideological variation, it never engages in radicalism or participates in anarchy.

7 See note 6 above.

8 For further information on this matter, see Fauzan Al-Anshari, Saya Teroris? (Sebuah Pledoi) (Jakarta: Republika, 2002). As the title implies (Am I a Terrorist? A Plea), this work explores Abu Bakar Ba'asyir's defense against accusations that he was involved in terrorist movements. 
and terrorism. In short, extremism provides fertile ground for nurturing and growing radical Islam or Muslim terrorists.

\section{“Islamic Extremism” in Indonesia}

In his 2005 book, Membongkar Jama'ah Islamiyah, Hery Sucipto refers to Nasir Abbas, the former head of Mantiqi (region) III in Jama'ah Islamiyah, a Southeast Asian Islamic extremist group that has been identified as a terrorist organization. Abbas states that extremist Muslims believe that enemies of Islam must be killed whenever they are found. Based on this idea, shedding the blood of the kafir (unbelievers) is permitted because they have waged war against the Muslim community in countries such as Palestine, Iraq, and Afghanistan. Accordingly, they consider U.S. citizens and their Western allies to be unbelievers, and attack places in Indonesia where many Americans or Australians gather, such as cafés, beaches, or embassies. ${ }^{9}$

Moreover, some teachers at Islamic boarding schools (pesantrens) in Indonesia have been found to have espoused extremist ideas, and some of their students or alumni have engaged in terrorist activities. One of these schools is Pesantren Al-Mukmin in Ngruki, headed by Abu Bakar Ba'asyir. This pesantren is accused of having disseminated extremist ideology and promoted the establishment of an Islamic state, and of preaching anti-American hatred. Ba'asyir himself is the head of the Majelis Mujahidin Indonesia (MMI), which is reported to have connections with the Jama'ah Islamiyah and $\mathrm{Al}$ Qaeda. ${ }^{10}$

It should be asserted here, however, that extremism and other forms of radicalism in Indonesia are not necessarily affiliated with—or sponsored by—religions, including Islam. Since the 9/11 tragedy, various Indonesian works and comments have criticized terrorist, radical, and extremist movements that have hijacked the name of Islam. These works have shown that terrorism or radicalism have no place in Islam, and should not be tolerated anywhere. ${ }^{11}$ Nahar bin Abdurrahman bin Nahar al-'Utaiby says that Islam has no connection to and no responsibility for any terrorist action in the world. Although those committing terrorist acts may be Muslim, they do not understand the true meaning of Islam. ${ }^{12}$

The act of labeling terrorism and extremism as "Islamic" has also undermined the Muslim community in general, and Indonesian Muslims in particular. The Indonesian Muslim community, by and large, rejects the extremist interpretations of Islam. Aisyah

9 Hery Sucipto, Membongkar Jama'ah Islamiyah (Jakarta: Grafindo Khazanah Ilmu, 2005), 249.

10 See Endang Turmudi and Riza Sahbudi, eds., Islam dan Radikalisme di Indonesia (Jakarta: LIPI Press, 2005), 133-39.

11 See Luqman bin Muhammad Ba'abduh, Mereka Adalah Teroris: Sebuah Tinjauan Syari'at (Malang: Pustaka Qaulan Sadida, 2005). The author criticizes the work of Imam Samudra, the "notorious terrorist," who wrote Aku Melawan Terorisme ("I am against Terrorism").

12 Nahar bin Abdurrahman bin Nahar al-’Utaiby, Islam Bukan Agama Kekerasan, Menolak Tuduhan Terorisme Terhadap Islam, translated by Hanif Yahya (Jakarta: Pustaka Al-Sofa, 2002). 
Hamid Baidowi, Head of the Center of Islamic Studies at Al-Hidayah Jakarta, represents this view. She has said that her organization would readily mobilize around seven million members of the Center to investigate or pressure those that teach or promote a misleading understanding of jihad (which, literally translated, means "strenuous effort”). ${ }^{13}$

The stereotyped belief that Islam is equal to terrorism will not increase our understanding of the nature of "Islamic" extremism or of the dynamics of Indonesian Muslim society. Instead, it could offend the Muslim community, and may motivate moderate Muslims to embrace radicalism.

It is more useful, I believe, to invite the Muslim community to participate in the global war on extremism or terrorism. In many ways, Muslim participation could effectively counter what we have been calling "Islamic" extremism.

\section{Countering "Islamic” Extremism}

Countering Islamic extremism cannot be the sole responsibility of any one government. All parts of society must cooperate in such an undertaking: the common people, Muslim organizations, political parties, and Muslim intellectuals must all participate.

\section{The Role of the Muslim People}

Cooperation between the government or security officers and the people is an effective means to countering the activity of extremist groups, because a large population can overwhelm the limited number of officers responsible for monitoring potential terrorist activity in the society. An example of efforts to forge such cooperation can be seen in the requirement for an outsider to report to local leaders whenever he or she enters a precinct. ${ }^{14}$ This report is forwarded to the security officers for future investigation, particularly when an act of terror occurs, especially in heavily populated cities like Jakarta and Bali. The discovery of the whereabouts of Dr. Azhari in Batu, Malang, attests to the significant role and involvement of the Muslim people.

\section{The Role of Muslim Organizations}

In Indonesia, two large social organizations, the NU (Nahdladul Ulama) and Muhammadiyah, play a significant role in countering the infiltration and development of extremist Islam. Not only are the NU and Muhammadiyah the two largest Muslim organizations in Indonesia, but they also share some cultural basis and platforms. Both represent mainstream, moderate forms of Islam that promote the concept of rahmah lil'alamin ("mercy used for all beings") and characteristics such as inclusiveness, moderation, tolerance, straightforwardness, equality, and prosperity. Their objectives and goals are nothing more than sustaining or empowering social justice, law enforcement, and people's prosperity within the frame of good governance. K. H. Hasyim Muzadi (NU) and Prof. Dr. Ahmad Syafi'i Ma'arif (Muhammadiyah) are two Muslim leaders

13 Kompas (23 November 2005), 4.

14 Media Indonesia (14 November 2005). 
par excellence who represent the Indonesian Muslim voice against terrorism and extremism. ${ }^{15}$

\section{The Roles of the Government and Political Parties}

Both the government and the political parties in Indonesia have played their legislative roles by issuing important regulations targeted at countering terrorism. On 18 October 2002, Indonesian President Megawati signed Executive Rule 1/2002 on "Eliminating the Crime of Terrorism.” Executive Rule 2/2002 followed, which retroactively extended rule 1/2002 to cover the 12 October 2002 terrorist attack in Bali. In order to make the rules more effective, they were passed as Indonesian legislation (15/2003 and 16/2003) on 4 April 2003. With these efforts, Indonesians have forged a base to effectively counter terrorism.

\section{The Role of Muslim Intellectuals}

In Indonesia, the ulamas (religious scholars) are a vital part of any effort to prevent the growth of extremism and terrorism, particularly at the level of ideology. The ulamas are not only experts on religious issues, but also have structural and cultural authority to issue decrees on religious matters (fatwa). K.H. Ma'ruf Amin, who heads the Fatwa Commission of the Ulama Council of Indonesia (the MUI), states: "terror and suicide bombing are forbidden in Islam. It is not jihad and martyrdom.”16 The MUI also analyzes how religious interpretations awaken radicalism and extremism. ${ }^{17}$

Another concrete action toward fostering global peace occurred during a gathering of Muslim intellectuals in June 2006 at the International Conference of Islamic Scholars II (ICIS II) in Jakarta. After official opening remarks by Indonesian President Susilo Bambang Yudhoyono, Jusuf Kalla, the Vice President, delivered an appeal to the Muslim communities to promote tolerance and democracy by strongly affirming the values of human rights. To counter extremist ideology, the Vice President also requested representatives from informal circles, such as those from madrasas (seminaries) and pesantrens (Muslim boarding schools), to pursue modernity through science and constructive dialogue. ${ }^{18}$

Although Muslims in Indonesia have made many efforts to counter extremism and terrorism, there are still some approaches that should be pursued further.

\section{Approaches to Countering “Islamic” Extremism}

Other alternatives can be employed to counter extremist ideology in Islam. In Indonesia, cultural, educational, ideological, psychological, political, and military approaches should be explored.

15 See Jamal Ma'mur Asmani, “Salafi Radikal, Pesantren, dan Terorisme,” Jaringan Islam Liberal (9 January 2003); available at http://islamlib.com/id/index.php?page=article\&id= 409.

17 Ibid.

18 Republika (20 June 2006). 


\section{Cultural Approach}

A cultural approach comes from within, namely from Muslim self-consciousness or reflection. Although this is a rather slow process through which to effect change, its influences are long-term. Muslim countries, such as Indonesia, that do not have radical or extreme cultures, can pursue efforts to directly or indirectly remind Indonesians that their culture emphasizes the virtues of tolerance, open-mindedness, friendliness, and progressiveness. Efforts to integrate Islam with local cultures can also promote similar values.

I must emphasize that Muslim countries such as Indonesia, although often accused of supporting terrorist, extremist, and radical networks, do not have violent cultures. Muslims in Indonesia generally are culturally moderate, as the followers of the Nahdhatul Ulama and Muhammadiyah, Indonesia's largest Muslim organizations, have demonstrated.

\section{Educational Approach}

Although education is usually considered a positive activity, it bears a neutral value. Education may be directed towards negative as well as positive goals. Quoting William O’Neil, education basically represents and transforms an ideology. ${ }^{19}$ Consequently, education becomes dangerous if it is infiltrated by some extreme ideologies, which are usually disseminated through a closed system of education.

Anticipating the risk posed by such extremist ideology, we need a formula for democratic and humanistic Islamic education. In Indonesia, I believe the existence of Islamic institutions and universities, such as IAIN/UIN, is a significant factor that could impact the nation's Muslim population. These institutions, even today, still reflect a mainstream view of democratic and moderate Islam. Certainly producing more moderate Muslims from such Islamic universities will be a positive development; these graduates are perceived to be accredited academic authorities, and are committed to the "valid" interpretation of Islam.

The same approach may be applied to traditional educational institutions, such as pesantren (Islamic boarding schools). To anticipate and discourage the spread of radical Islam, a Muslim summit and conference, entitled "The Development and Cooperation of the Pesantrens in Countering Religious Radicalism" ("Pengembangan dan Kerjasama Pondok Pesantren dalam Menanggulangi Radikalisme Keagamaan”), met at Asrama Haji Medan, on 1-3 October 2004. The conference's agenda focused attention on radicalism and extremism as the wrong path, representing a deviation from Islam. To decrease the appeal of extremist ideology, the conference recommended that pesantrens should fulfill their obligation to produce well-educated graduates instilled with integrative, open-minded, and inclusive characteristics; pesantrens should implement open management processes; pesantrens should promote the theology of affec-

19 See William F. O’Neil, Educational Ideologies: Contemporary Expressions of Educational Philosophies (Santa Monica, CA: Goodyear Publishing Company, 1981). 
tion and peace; and that pesantrens should attempt to establish an inter-faith dialogue with non-Muslims to create mutual understanding and avoid religious polarization.

\section{Religious/Ideological Approach}

The distinction between religion and ideology is narrow. Both are defined in terms of vision, mission, and goals. Islam, as a religion, is more than an ideology; it is also a moral code, and a belief system about ultimate reality. In contrast, ideology is associated with politics. An "ideologized" religion, therefore, is nothing more than a process that reduces the value of religion itself.

Looking at extremist Islam's underpinnings from a religious-ideological perspective would shed light on extremist attitudes and beliefs. It would also demonstrate the chasm between legitimate religious teachings and the acts committed by terrorists. This approach attempts to understand all aspects of Islam, from the ulamas, or religious scholars; the ustadzs, or religious teachers; and Muslim intellectuals. These institutions are intended to convey a "true" understanding of Islam, and to provide good examples for the Muslim people.

Jusuf Kalla, the Vice President of Indonesia, has said that the Indonesian war on terrorism will be more effective if it is bolstered by ideological support from the ulamas, the ustadzs, and the kyais. Kalla believes that this support is vital in the effort to sever ties within the terrorist network and to discourage new recruits from joining terrorist ranks. ${ }^{20}$

\section{Psychological Approach}

Understanding the psychology of terrorism—specifically, understanding how and why Islamic terrorist and extremist networks function-is critical if we want to prevent further expansion of these networks. The rapid increase of Islamic terrorists and extremists has shocked the Muslim community in Indonesia. Terrorist leaders, who with skill and seeming ease recruit and train new followers who morph into militants, have certainly succeeded in capturing our attention. Given the fatwa issued by the ulamas (MUI) that prohibits these networks and activities, why do radicalization and extremism still occur?

Komaruddin Hidayat, director of the Postgraduate Program at the State Islamic University (UIN) in Jakarta, investigated the problem and concluded that injustice, intimidation, and social marginalization eventually result in delayed psychological responses that lay the foundation for terrorism. ${ }^{21}$ To address this situation, he suggested that all sides come together and share information honestly and openly in an attempt to solve problems by pursuing strategic and humanized actions.

\section{Political Approach}

A political approach incorporates an effort to establish a political network untainted by terrorist and extremist infiltration. This requires intensive professional cooperation, be-

20 Kompas (23 November 2005), 4.

21 Komaruddin Hidayat, "Psikologi Terorisme,” in Kompas (23 November 2005), 6. 
cause terrorists and extremists have cast a wide network and spread their influence to many countries. ${ }^{22}$ Terrorism and extremism have become extraordinarily transnational, and operate without regard to borders.

Anticipating that radicals or extremists will be active politically will limit their success. It will be more difficult for them to win sufficient seats in parliament, where they could transform their ideas and ideologies into national legislation or obstruct legislation that they oppose. So far no extremist group has won seats in the Indonesian Parliament. Executive rules 1/2002 and 2/2002 on "Eliminating the Crime of Terrorism," as well as Indonesian legislative acts 15/2003 and 16/2003 on the same issue, illustrate that the parliament has not been infiltrated by the power of extremists.

In contrast, Egypt's moderate Muslims feel continually threatened by extremists. Article 161 of the Egyptian Penal Code imposes three years of imprisonment and fines ranging from $\mathrm{£100}$ to $E £ 500$ on those who publish material or act in any way against the commonly accepted standards of Egypt's faith. According to Al-Asymawi, only militant Muslims reject Article $161 .^{23}$

\section{Military Approach}

A military approach must be considered a last resort if other approaches fail to deter extremism or terrorism. Military action describes any government or police effort to prevent a terrorist action or attack. Indonesian police pay close attention to Islamic extremist organizations, such as Hizb ut-Tahrir Indonesia and Front Pembela Islam (Islamic Defense Front). These organizations often use physical force to promote their ideas or convictions. An Indonesian Police spokesman, Brigadier General Anton Bachrul Alam, says that it is possible to disband an Islamic mass organization if it persistently pursues violent solutions. ${ }^{24}$ In a larger context, the military approach must be considered very carefully. George Soros, the Director of the Open Society Institute, warned that the military approach can be counterproductive and create a vicious circle of terrorism. ${ }^{25}$

\section{Epilogue}

Islamic extremism is not a new phenomenon in Islamic history. The Kharijities in classical Islam were the earliest extremists. Although extremism may be an internal dynamic within Islam and Muslim society, it may be found in other religions as well. Efforts to counter Islamic extremist ideology should come from within the Muslim communities.

22 See M. Imadudin Rahmat, Arus Baru Islam Radikal; Transmisi Revivalisme Islam Timur Tengah ke Indonesia (Jakarta: Erlangga, 2005), 26-27.

Al-'Asymawi, Against Islamic Extremism, 123. One well-known case is that of Nasir Hamid Abu Zaid, who under legal force was divorced from his wife for his controversial work that many believe to be an assault on the Koran.

25 Kompas (7 January 2006). 
In Indonesia, several efforts to counter extremism have been made simultaneously. These efforts have included Indonesian Muslims in general, as well as the government, parliament, and Muslim organizations and intellectuals. Several approaches-for example, the cultural, educational, ideological, psychological, political, and military approaches - could be described in greater detail. Mutual cooperation with foreign governments or organizations may also be fostered without interfering too much in the internal affairs (particularly any hidden political interests) of the Muslim community. These approaches will be more effective if they are coordinated. One-sided action will not only waste energy, but will create uncertainty.

In the future, additional efforts to create peace and global justice are vital. Extremism, radicalism, and terrorism are basically psychological expressions that occur whenever and wherever injustice, intimidation, and insecurity exist. Overcoming these problems requires cooperation and mutual understanding from everyone involved; measures to counter extremism, radicalism, and terrorism must not be implemented inequitably, nor should they support the interests of one group at the expense of another group.

The former Secretary-General of the United Nations, Kofi Annan, has said that combating terrorism must not be done at the expense of human rights and civil liberties. If we do not follow his warning, our efforts will be fruitless and may result in the victory of the terrorists. ${ }^{26}$ Confronting terrorism by pursuing another form of terrorism will only create more terrorism, thus resulting in a vicious circle that offers victory to no one.

26 Republika (20 June 2006). 
WINTER SUPPLEMENT 2006

\section{Bibliography}

Asmani, Ma'mur. "Salafi Radikal, Pesantren, dan Terorisme." Jaringan Islam Liberal(2003).

Esposito, John L.. The Islamic Threat: Myth or Reality? . Oxford: Oxford University Press, 1992, 1992.

Hencke, David, and Hugh Mair. "Kelly: Imams Failing to Deter Extremism." The Guardian (U.K.) (2006).

Hidayat, Komaruddin. "Psikologi Terorisme." Kompas (2005).

Luqman bin Muhammad Ba'abduh, Mereka Adalah Teroris: Sebuah Tinjauan Syari'at . (Malang: Pustaka Qaulan Sadida, 2005.

M. Rahmat, Imadudin. Arus Baru Islam Radikal; Transmisi Revivalisme Islam Timur Tengah ke Indonesia. Jakarta: Erlangga, 2005.

O’Neil, William F.. Educational Ideologies: Contemporary Expressions of Educational Philosophies. Santa Monica, CA: Goodyear Publishing Company, 1981.

Sucipto, Hery. Membongkar Jama'ah Islamiyah. Jakarta: Grafindo Khazanah Ilmu, 2005 . 